\title{
参照構造を持つXML上の高速な到達可能性判定
}

\section{Fast Reachability Test on DAGs for XML}

\author{
$\underset{\text { Yusaku Nakamura }}{\text { 有作 }}$ \\ 舞田 哲哉 \\ 坂本 比呂志
}

九州工業大学 情報工学研究科

Graduate School of Computer Science and Systems Engineering, Kyushu Institute of Technology yuusaku@donald.ai.kyutech.ac.jp

(同上)

t_maita@donald.ai.kyutech.ac.jp

九州工業大学 情報工学部

Faculty of Computer Science and Systems Engineering, Kyushu Institute of Technology hiroshi@ai.kyutech.ac.jp

keywords: XML, range labeling, ancestor-descendant relationship, directed acyclic graph

\section{Summary}

We propose an efficient algorithm for deciding the reachability between any nodes on XML data represented by connected directed graphs. We develop a technique to reduce the size of the reference table for the reachability test. Using the small table and the standard range labeling method for rooted ordered trees, we show that our algorithm answers almost queries in a constant time preserving the space efficiency and a reasonable preprocessing time.

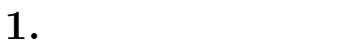

本研究の目的は, XML に代表される半構造データ上 で, 複雑な問い合わせ式の評価を行うための基礎的な技 術である，任意のノード間の先祖子孫関係や到達可能性 を高速に判定するための手法を提案することである .

XML は ,計算機可読な情報のデータ交換のための標準 フォーマットとして認知され，日々莫大なデータがXML としてネットワーク上に蓄積されている．XML は制約 の緩やかなフォーマットであるため, 樣々な場所で自由 に記述，蓄積されており，このような XML から目的の データを高速に取り出すために, XQuery [Betc02] など のXML のための問い合わせ言語か提案されている .

これらの問い合わせ言語において, 複雑な問い合わせ 式を評価するための基盤となるのが，任意のノード間の 先祖子孫関係や，より一般的なグラフ上の到達可能性を 高速に判定する技術である.範囲ラベルは光の手法のひ とつであり，通常は，データとなる順序木の各ノードに， 前置順と後置順の順位のペアを設定したものである .こ のとき, ラベル $(x, y),(u, v)$ に対して,$x<u$ かつ $y>v$ であることと $(x, y)$ が $(u, v)$ の先祖であることは等しい . このとき， $(x, y)$ は $(u, v)$ を包含するという . このよう に前処理としてこの範囲ラベルを計算することで , 任意 のノード間の先祖子孫関係を定数時間で判定できる .

範囲ラベルに対しては, 弚の原理の単純さや応用の広 さから樣々なアルゴリズムが提案されている $[$ Cohen02,
Abiteboul01, Zhang01, 江田 02] .一方，一般の XML データを記述するためには，順序木よりも広いクラスで ある非巡回グラフのクラスまで拡張する必要がある*1.し かしながら，非巡回グラフは辺の合流を含むので，単純 な範囲ラベルでは, 非巡回グラフ上の無矛盾な先祖子孫 関係を保存することができない，実際に，どのような範 囲ラベルを用いても正しい到達可能性を表現することが 不可能な非巡回有向グラフの例が存在する .

このような問題点を解決するために，これまでに樣々 な工夫が提案されている . 非巡回グラフの範囲ラベル付 けとして [Agrawal89] の手法がある .この手法では , ま ず,与えられたグラフの全域木を求め, 弚れに対して範囲 ラベルを設定する．光してすべての葉ノードから根に向 かって木以外の辺も辿ることで範囲ラベルの伝播を行う . このとき，あるノード $u$ のすべての範囲ラベルが，ノー ド vのある範囲ラベルに包含されるときまた光のときに 限り, $v$ から $u$ へ到達可能となる . この手法の効率は, 各 ノードに設定される範囲ラベルの最大数 $p$ に依存する.

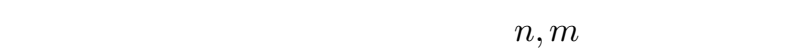
な前処理時間は $O(p m)$ であり，記憶領域は $O(p n+m)$ である．また，範囲ラベルがソートされていると仮定す ると, 1 回あたりの判定は $O(p)$ 時間となるが, 最悪の場 合 $p=O(n)$ となる.

*1 巡回を含む連結な有向グラフは，強連結成分に分解すること で非巡回グラフの場合に還元できる .これについては後述する 
この欠点を改善する手法として , [鳥井 06] では, 重な り範囲ラベルと多次元分割による判定法が提案されてい る .これは , 元の非巡回グラフをいくつかの連結成分に

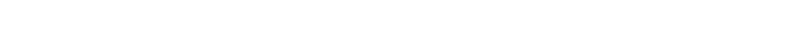
単一の範囲ラベルで到達可能性を保持できる極大部分グ ラフとなっており, 同じ成分内のノードについては定数 時間で到達可能性を判定できる.この手法では, 1 回あ たりの判定時間は, 多次元分割の個数 $q$ に比例し，この 值は, [Agrawal89] の手法における $p$ に比べて比較的小 さいことが示されている [鳥井 06] .この手法における前 処理時間は $O\left(q n^{2}\right)$, 記憶領域は $O(q(n+m))$ である.

[Agrawal89] の伝播法は，前処理の時間は抑えられる ものの，複雑なデータでは，1ノードあたりの範囲ラべ ルの個数が急激に増加することが報告されている [鳥井 06] . また , [鳥井 06] の手法では判定コストは抑えられる が , グラフの多次元分割に要するコストが高いため大規 模データに対する実装が難しい。

一方 , 範囲ラベルとは異なる手法として 2-Hop-Label 法が提案されている [Kaplan02] .この手法は , ラベルに よって到達可能性を判定するという点については他の手 法と同樣であるが，二つのノードが共通のラベルを持つ か否かによって到達可能性を判定するという点が異なる [Schenkel05]は，この手法を改良し，大規模なデータに 対する実装が可能なアルゴリズム HOPI を提案している . この手法も判定時間はラベル数に比例するが，各ノード の平均ラベル数は光れほど大きくならないことが実験に よって示されている. 乥こで本研究では，この手法を比 較対象とする。

本研究では, 前処理の時間と記憶容量に関するコスト を妥当な範囲に抑えながら，XML が表現する有向グラ フ上で , ノード間の到達可能性を高速に判定するアルゴ リズムを提案する．有向グラフを表現するXML の技術 として，別々のデータを双方向に関連付けたり外部から リンク構造を定義するXLink/XPointerやメタデータを 記述するためのセマンティック Web の技術である RDF など，樣々なものが存在する．

乥こで, 本研究が対象とする XML と乥れが表す構造 を説明する．XML は，より一般的な概念である半構造 データに含まれる，半構造データは，形式的には，属性 と光の值のペアからなる列あるいは集合であり，值は文 字列や数值などの基本データ型または半構造データであ ると定義される.本研究が対象とする XML では，この ような構造は，次のようにラベル付きグラフで表現され る . 属性はグラフのノードに対応し，属性間の二項関係 がノード間の辺に対応する．すなわち，属性が直近の入 れ子関係にあるときや，特定の異なる属性が同じ值を持 つときに，弚のノード間に辺を定義する．XML では半 構造データの属性のことを要素と呼ぶ . 本論文では, 要 素間の入れ子によって定義される辺を実辺，要素の值に よって定義される辺を参照辺と呼ぶ。
参照辺は要素に付加的に定義される特定の属性と光の 值の組によって定義される .例えばXMark [Schmidt02] では，ある要素の ID 型属性と別の要素の IDREF 型属 性が同じ值を持つことで, この 2 要素間の参照辺を実現 している.この参照辺は, XLink で記述される単純リン クに相当する .

本研究のアイディアは, XML データが以下のような 偏りを持っているという仮定に基づいている .

（1）サイズが増加しても深さはほとんど変化しない，

（2）参照辺は特定のノードを参照する傾向がある.

（3）実辺のみからなるパス上にあり，参照辺によって 参照されているノード数は, パス 1 本あたり一定数 に抑えられる .

これらの性質は，XMark [Schmidt02] による樣々な サイズのデータをはじめ, 弚れ以外の実データにおい ても観察される.光こで本研究では，これらの性質を持 つような非巡回グラフに対して高速な到達可能性判定 アルゴリズムを実装し，異なる XML データに対して， 前処理時間，記憶領域，判定時間の測定を行う．また， HOPI [Schenkel05] を実装して同じ XML データに対し て実験を行い，本手法の効果を確認する．

本研究で提案する手法は，木の範囲ラベルと参照テー ブルを組み合わせた手法である . まず [Agrawal89] と同 樣に, 非巡回グラフの全域木を求めて木の範囲ラベルを 計算する. 乥して，弚の範囲ラベルで判定できないノー ドについてのみ参照テーブルを作成する .

参照テーブルは，すべての 2 ノード間の到達可能性を 1 ビットで保存すると $\Omega\left(n^{2}\right)$ サイズの配列が必要となる が, 本研究では, この参照テーブルを二つに分割するこ とで, サイズを削減する．実際に，判定時間をほとんど 損なうことなくXMark のデータでは，この配列のサイ ズを $1 \%$ 未満に削減できることを実験によって示す．ま た , XMarkよりも参照辺の割合が高い実データに対して も，この配列のサイズは $4 \%$ 未満に抑えられている.イ ンデックスを作成するための前処理時間は，10MB 程度 までの実験では，十分な規模耐性を持っていることを示 す . 判定時間も範囲ラベルの高々 1 回の比較と参照テー ブルへのほぼ 1 回のアクセスで可能であり，高速である .

本論文の構成は以下のようになっている.2 節では, 本 研究に関連する概念, 特に, 範囲ラベルやグラフ理論に 関する基本的な性質をまとめる. 3 節では, 本研究で提 案するアルゴリズムとデータ構造を示す .4 節では，本 手法を実装し，XMark と光の他の実データに対する各種 計算時間を測定し, 光の有効性を示す.また, HOPI と の比較実験によって，本手法の判定時間においての優位 性を示す . 5 節では, 本研究の成果と今後の課題をまと める . 


\section{2. 準備}

本節では，XML と有向グラフの関係や基本的な範囲 ラベルの性質について簡単にまとめる .

\section{$2 \cdot 1 \mathrm{XML}$ の木構造と範囲ラベル}

XML はマークアップ言語であり, タグを用いて階層構 造を記述できる . 1 つの開始タグは対応する終了タグを 持っており，乥れらを合わせて要素と呼ぶ 。このような XML の階層構造は, DOM (Document Object Model) と呼ばれるデータモデルによって，根付き順序木で表す ことができる . 木のノードラベルは, 元の XML のある 要素名に対応する.このような木構造に対して，範囲ラ ベルの定義を与える .

【定義 1】有向グラフ $G$ の任意のノード $v$ に ある非 負整数のペア $(\ell(v), r(v))$ を割り当てたとき，任意の $v, u$ に対して，" $\ell(v)<\ell(u)$ かつ $r(v)>r(u) "$ と “ $v$ が $u$ の 先祖である”が等価であるとき，この割り当てを $G に$ 対 する範囲ラベルという .

$G$ が木や平面グラフなど単純な構造であるときには， このような性質を満たす範囲ラベルは高速に計算するこ とができる，例えば木の場合には，谷のノード $v$ の前置 順と後置順による順位のペア $(\operatorname{pre}(v), \operatorname{post}(v))$ を利用す る手法がよく知られている .このようにしてラベル付け された例を図 1 に示す .

より一般には, 各 $\operatorname{pre}(v)$ や $\operatorname{post}(v)$ の間隔を空けて 設定することで，範囲ラベルの条件を満たしながらデー タの挿入や削除に対応することができる [江田 02] .した がって，弚れらすべてを広義の範囲ラベルと考える.こ のような範囲ラベルを設定することで, 任意の 2 ノード について , 一方が他方の先祖であるか否かを 2 つの整数 の比較のみで判定できる

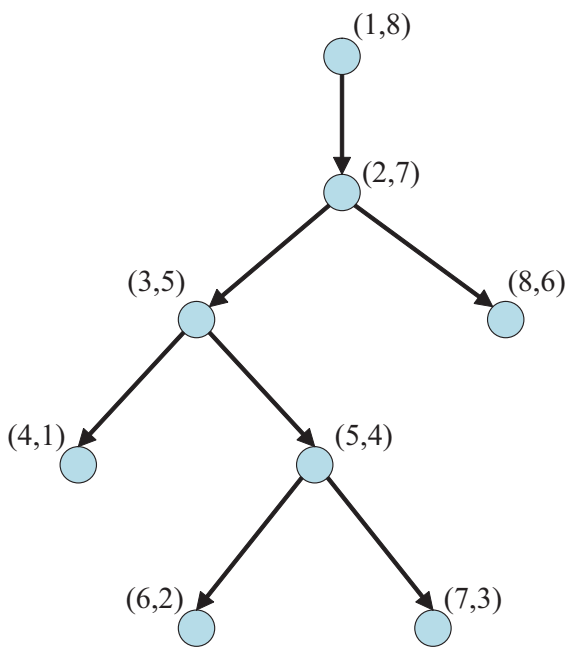

図 1 根付き順序木の範囲ラベル

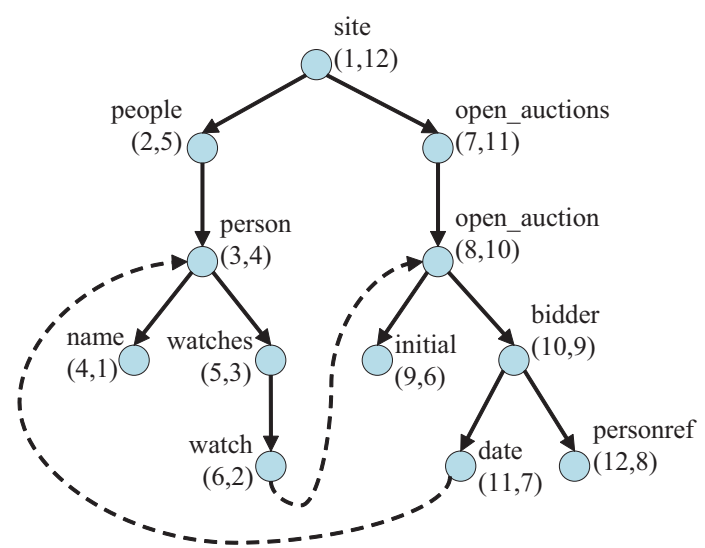

図 2 参照構造を持つXML: person と open_auction がある 属性値を ID 型として持ち, date と watch が IDREF 型の属性値として乥れらと同じ值を持つ.

\section{$2 \cdot 2$ 非巡回グラフ}

XML がより複雑な構造を持つ場合の判定問題を考え る.XMark では，ID 型および IDREF 型と呼ばれる属 性がタグ内で定義されており，ID 型の属性值と同じ值 を，IDREF 型で参照することで，あるノードから任意 のノードへ仮想的なリンク構造を表現できる (図 2).こ のような構造を含んだ XML は, 連結な有向グラフと等 価であり，弚の有用性から，このような構造に対しても 先祖子孫関係や到達可能性を高速に判定したい．

ここで, 巡回を含む連結な有向グラフに関する到達可 能性の判定は，以下のように非巡回に制限した場合に還 元できる.任意の有向グラフは , 乥のグラフの深さ優先探 索を 2 回行うことで, 弚のグラフを強連結成分に分解で きる [Aho87] . 強連結成分とは, 互いに到達可能なノー ドだけで構成された部分グラフのことであり $, x, y$ が同 一の強連結成分内のノードであるならば，任意のノード $z$ に対して, $z, x$ 間の到達可能性と $z, y$ 間の关れは等価で ある．したがって，1つの強連結成分全体を 1 つの頂点で 置き換えてよく，このようにして再構成されるグラフは 非巡回有向グラフになる．したがって，以降では，非巡 回グラフ (DAG) に関する到達可能性のみを考える . ま た，DAG 内における先祖子孫関係の概念を木の場合と 同樣に使用する．すなわち， $x$ から $y$ への有向パスが存 在するとき, $x$ は $y$ の先祖,$y$ は $x$ の子孫という .

次に，一般の DAG に対して範囲ラベルを設定するこ とを考える.あるDAG $G$ が与えられたとき， $G$ の全域 木を $T$ とし， $T$ に対する範囲ラベルを通常の方法で設定 したとする .このとき， $G$ に合流辺がないならば $T=G$ となり，Gの範囲ラベルが完成するが，一般には $T \neq G$ であるので，ある頂点同士が先祖子孫関係にあるのに定 義 1 の関係が成り立たないことが起こりうる

［定理 1] 無矛盾な範囲ラベル付けが不可能な非巡回 有向グラフ $G$ が存在する. 
《証明》ノード数 $n$ の有向グラフに範囲ラベルか存在す るとする . 各ノード $v$ のラベル $(\ell(v), r(v))$ に対して , ラ ベル $(\ell(v), r(v)+n)$ を考えると，これもまた光のグラフ の範囲ラベルであり， $\ell(v)<r(v)+n$ を満たす .このとき $[\ell(v), r(v)+n]$ は数直線上の閉区間である . したがって， ある有向グラフに対して , “ $v$ から $u$ へ到達可能である” と “[ $\ell(v), r(v)+n]$ が $[\ell(u), r(u)+n]$ を含む”か等価となる 閉区間を構成できないことを示せばよい．ここで， $G=$ $(V, E), V=\left\{v_{i}, u_{i} \mid 1 \leq i \leq 3\right\}, E=\bigcup_{i \neq j}\left\{\left(v_{i}, u_{j}\right)\right\}$ とす る (図 3 ). $G$ のノード $u_{1}, u_{2}, u_{3}$ は互いに到達不可能で あるので, これらに割り当てられる区間は, 少なくとも $\ell\left(u_{i}\right)<\ell\left(u_{j}\right)<\ell\left(u_{k}\right)$ を満たす必要がある ${ }^{* 2}$. ただし， $(i, j, k)$ は $(1,2,3)$ の任意の置換である.$v_{1}$ は $u_{2}, u_{3}$ の みの先祖であり, $v_{2}$ は $u_{1}, u_{3}$ のみの先祖であるので, 可 能な割り当ては, $\ell\left(u_{1}\right)<\ell\left(u_{3}\right)<\ell\left(u_{2}\right)$ または $\ell\left(u_{2}\right)<$ $\ell\left(u_{3}\right)<\ell\left(u_{1}\right)$ のみである.しかしどちらの場合も , $u_{1}, u_{2}$ の区間を含んで $u_{3}$ の区間を含まないような区間は存在 しない、したがって，Gに無矛盾な範囲ラベルは存在し ない。

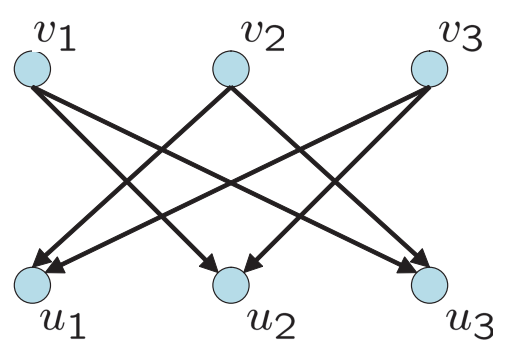

図 3 範囲ラベル付け不可能な非巡回グラフ

このように,単一の範囲ラベルでは, DAG に無矛盾 なラベル付けを行うことはできない，光こで，本研究で は，範囲ラベルでカバーできない関係を，小規模な参照 テーブルにあらかじめ登録する手法を提案する .

\section{3. 提 案 手 法}

すでに説明したように，本研究では対象とする XML データの参照構造として，属性間の值によって定義され るものを想定している .

\section{$3 \cdot 1$ 非巡回グラフと全域木の関係}

XML 内に ID 型と IDREF 型の属性が定義されている とする.あるID 型の属性値を持ったノードを IDREF 型 によって参照しているノードを参照ノード，参照されて いるノードを被参照ノードと呼ぶ . ID 属性が定義されて いても実際に光れが他から参照されていない場合は，乥 のノードは被参照ノードとは見なさない .

$* 2$ 等号が成立すると一方が他方の部分区間となり矛盾する
また , XML 内で記述されている要素間の関係を 2 種類 に分類する.すなわち，弚のXML の DOM 木における 親子関係を表す辺を実辺と呼び, 参照ノードから关れが参 照している被参照ノードへの辺を参照辺と呼ぶ . 例えば，

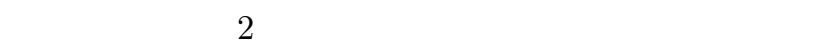
外の辺が実辺を表す．また, person と open_auction 夕 グを持ったノードが被参照ノードであり，光れらは date と watch タグを持つノードから弚れ光れ参照されている。

有向グラフ $G=(V, E)$ に対する全域木 $T_{G}$ を求めたと き, $E$ の辺のうち $T_{G}$ に属さない辺の集合 $E^{\prime}=\{e \mid e \notin$ $\left.T_{G}\right\}$ は, 以下の 3 種類に分類される. 本研究では, $T_{G}$ の辺は実辺，乥れ以外の $E^{\prime}$ が参照辺に該当する.

(a) 前進辺: $T_{G}$ の頂点から光の子でない子孫への辺

(b) 後退辺 : $T_{G}$ の頂点から先祖への辺

(c) 交差辺：光れ以外の辺

$T_{G}$ に任意の前進辺を付け加えた $T_{G}^{\prime}$ に関する到達可能 性は， $T_{G}$ の乥れと等しい.したがって， $T_{G}$ の範囲ラベ ルか赇まっているとすると，(a)の前進辺は無視できる．

$T_{G}$ にある後退辺を付け加えたとき，ある閉路ができ る.この閉路に属するノードは, 到達可能性に関して等 価である．したがって，前処理として強連結成分に分解 することによって，(b)の後退辺はないものとみなせる．

以上により，Gのノード間で到達可能であるものは， 弚れらが $T_{G}$ 上で先祖子孫関係にある場合と， $T_{G}$ の辺と (c) の交差辺のみをたどるパス上にある場合のいずれか となる.したがって, 到達可能性において前進辺と後退 辺は無視できることから，議論する必要があるXML 上 の参照辺は，交差辺のみである .

\section{$3 \cdot 2$ 参照テーブル}

$n$ を有向グラフ $G$ のノード数とすると, $n \times n$ の配列 $R$ で, $v_{i}$ から $v_{j}$ ヘパスが存在するとき $R_{i j}=1$, 光れ 以外のとき $R_{i j}=0$ を満たすものを $G$ の到達可能性に対 する参照テーブルという . この配列のサイズは $\Omega\left(n^{2}\right)$ で あるが， $G$ は非巡回であるとしてよいので， $G$ の頂点を トポロジカルソート $[\mathrm{Aho87}]$ し，Rの行列の添字をこの ソート順にすることで, サイズを半分にできる．なぜな らば，トポロジカルソートで順位か下位のノードから上 位のノードへの辺は存在しないからである .

しかしながら，この手法では配列のサイズが $G$ のノー ド数 $n$ に対して， $\frac{n(n-1)}{2}$ になるだけで, 大規模なデータ に適用することは困難である．弚こで，前述したような XML データに含まれる偏りに着目して，この配列のサイ ズを削減することを試みる．次の定義は， $v_{i}$ から $v_{j} へ の$ 到達可能性において始点 $v_{i}$ に関する制限を表している.

【定義 2】 DOM 木 $T$ 上のノード $v$ を根とする部分木 $T_{v}$ が参照ノードを含まず,$v$ の親を根とする部分木が参 照ノードを含むとき， $T_{v}$ を $T$ の極大部分木という . 


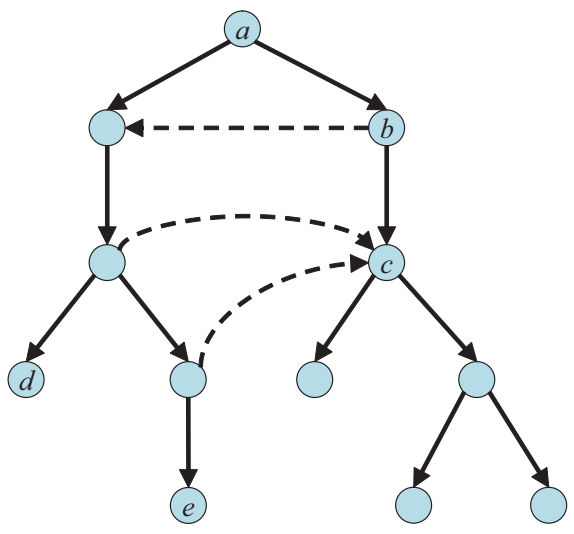

図 4 極大部分木と単純ノードの例 : $a, b$ のみ が単純ノードで, $c, d, e$ を根とする部分 木のみが極大

極大部分木は, 外部のノードを参照しないノードだけ からなるDOM 木の極大な部分木を表している．したがつ て， $v_{i}$ がある極大部分木のノードならば, 参照テーブル の行要素に $v_{i}$ は不要である.なぜならば， $v_{i}$ から到達で きるすべてのノードは关の極大部分木内に限られ，弚れ らは範囲ラベルのみで判定できるからである . 同樣にし て，以下の定義によって終点に関する制限を行う。

【定義 3】DOM 木 $T$ のノード $v$ が自分も含めて先祖 に被参照ノードを持たないとき, $v$ を単純ノードという．

ある頂点 $v_{j}$ が単純ノードならば，参照テーブルの列 要素に $v_{j}$ は不要である.なぜならば， $v_{j}$ に到達できる すべてのノードは $v_{j}$ の DOM 木における先祖に限られ， 弚れらはやはり範囲ラべルのみで判定できるからである． 図 4 に，極大部分木と単純ノードの例を示した .

以上の概念から，参照テーブルで必要な情報は，子孫 に被参照ノードを持つノードから，先祖に被参照ノード を持つノードへの到達可能性の情報のみである . 乥こで， 深さ優先探索を行うことで, 配列 $R_{i j}$ の添字 $i$ を, 子孫 に被参照ノードを持つノード $v_{i}$ に関連付け，添字 $j$ を先 祖に被参照ノードを持つノード $v_{j}$ に関連付ける . 次に， このように定義した参照テーブルを実際に構築するアル ゴリズムを説明する .

\section{$3 \cdot 3$ アルゴリズム}

参照テーブルの構築法を説明する . 範囲ラベルの構築 については省略する . DOM 木の深さ優先探索によって， 子孫に被参照ノードを持つノード $v$ の系列 $v_{i}$ と先祖に 被参照ノードを持つノード $u$ の系列 $u_{j}$ がすでに求まっ ており，これらの添字は発見された順番に定義されてい るものとする . このとき，参照テーブル $R_{i j}$ の $i$ 行目を $v_{i}$ と関連付け, $j$ 列目を $u_{j}$ と関連付ける .したがって $R_{i j}=1$ のときまた炎のときに限り， $v_{i}$ から $u_{j}$ へ到達可 能と判定する .
アルゴリズム $D F S(T)$

入力 : XML の DAG $T$ (DOM 木 + 参照辺)

出力 : 到達可能性を記録した配列 $R$

(1) $T$ の実辺を深さ優先探索し，あるノード $u$ から光の 親 $v$ に戻るときに，uの現時点での子孫を $v$ の子孫 として $R$ に記録する

(2) 参照ノード $v_{i}$ があれば，弚の参照先 $u_{j}$ に対して $D F S\left(T_{u_{j}}\right)$ を呼び出す

(3) 呼び出しが終われば, $u_{j}$ の子孫を $v_{i}$ の子孫として $R$ に記録する

図 5 参照テーブルの構築アルゴリズム

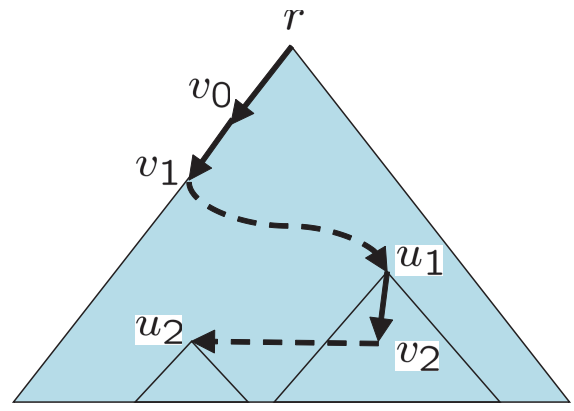

図 $6 D F S(T)$ の巡回: 被参照ノード $u$ を根とする 部分木のノードを兴の親 $v$ へ伝播させていく

図 5 に参照テーブルの構筑アルゴリズム $D F S(T)$ を 示した . このアルゴリズムの概略と使用するデータ構造 を説明する . 入力は XML を DOM 木で表したリスト構 造で，参照・被参照の関係を含んだ DAG である .この データ構造 $T$ の実辺を深さ優先探索しながら，各ノード から到達可能なノードを参照テーブル $R$ に記録していく .

あるノード $v_{i}$ に対応する参照テーブルの $i$ 行目には， 現時点までにわかっている $v_{i}$ から到達可能なノードが記 録されている．したがって， $v_{i}$ の子孫をすべて求めるた めには， $v_{i}$ の子供 $v_{j}$ の子孫を求めて $R$ に登録し，深さ 優先探索で親である $v_{i}$ に戻るときに,$R$ の $j$ 行目を $i$ 列 目に継承すればよい．ここで継承とは，1 (true) のビッ トのみをコピーすることを意味する . 親へ戻るためには , 弚れまでの先祖をスタックに積んでおけばよい．

また，あるノードが参照ノードならば，対応する被参 照ノードを訪れて，弚のノードを根とする部分木に対し て再帰的に上記の動作を行う . 部分木の巡回が終わった ときは,上と同樣に参照元に対して子孫の継承を行う .こ の動作によるDAG の巡回を 図 6 に示す .

$T$ は閉路を含まないので, $D F S(T)$ の処理は必ず終了 する．しかし $T$ が合流を含むとき，スタックだけでは同 じ頂点を 2 度以上訪れることがある .この問題は, 上記 の子孫の継承によって回避できる . ある頂点 $v_{i}$ を 2 度 目に訪れたとき, 最初の探索の時点で $v_{i}$ の子孫は $R$ の $i$ 
行目にかならず記録されている．なぜならば，Tは閉路 を含まず，アルゴリズムは深さ優先探索を行っているの で, $v_{i}$ から始まる 1 度目の探索で, $v_{i}$ に継承されるべき 子孫はすべて到達済みだからである．したがって，探索 を弚こで打ち切って，スタックに積まれているノードに $v_{i}$ の子孫すなわち $R$ の $i$ 行目を継承すればよい . この参 照テーブル $R$ はすべてのノードの組み合わせに対して領 域を確保する必要はなく，弚の実際の効率は実験によっ て示される。

アルゴリズム Reachability $\left(v_{i}, v_{j}\right)$

入カ : XML の DAG T の参照テーブルのと範囲ラベル 出力: $v_{i}$ から $v_{j}$ へ到達可能性

(1) $v_{i}$ の範囲ラベルが $v_{j}$ の乥れを包含するならば到達 可能, 弚れ以外なら次へ

(2) $v_{i}$ が $T$ の極大部分木に含まれるか $v_{j}$ が単純ノード ならば到達不可能, 光れ以外なら次へ

(3) $R_{i j}=1$ ならば到達可能, 兴れ以外なら到達不可能

図 7 DAG 上の到達可能性判定アルゴリズム

$D F S(T)$ と $T$ の範囲ラベルを用いて，任意の頂点間 の到達可能性を判定するアルゴリズムを 图 7 に示す .も し 2 ノード間にDOM 木中の先祖子孫関係があるならば 弚れは範囲ラベルで判定可能である.また产れ以外て到 達可能ならば，弚のようなパスは必ず参照辺を少なくと も 1 つは含む . 参照ノードを子孫に持つノードと被参照 ノードを先祖に持つノードの到達可能性は $R_{i j}$ に記憶さ れているので, 結局任意の頂点間の到達可能性を範囲ラ ベルと参照テーブルドけで判定可能である .

アルゴリズムの時間/領域計算量を見積もる . DOM 木 のノード数を $n$ ，参照辺を含んだ辺の総数を $m$ とする . まず $D F S(T)$ について，必要なデータ構造はスタック， DOM木，参照テーブルである.スタックのサイズは $O(n)$ であり，DOM 木のサイズは $O(n+m)$ である . また , 被 参照ノードの個数を $\ell$, 先祖に被参照ノードを持つノー ドの個数を $\ell^{\prime}$, 子孫に被参照ノードを持つノードの個数 を $k$ とすると，参照テーブルのサイズは $O\left(k \ell^{\prime}\right)$ である .

したがって , $D F S(T)$ の領域計算量は $O\left(n+m+k \ell^{\prime}\right)$ となる．最悪の場合，これは $O\left(n^{2}\right)$ である．また，範囲 ラベルは $O(n+m)$ て計算可能で, $D F S(T)$ は各辺を一 度しか辿らず, $R_{i j}$ の各成分を一度しか更新しないので， $D F S(T)$ の時間計算量は， $O\left(n+m+\ell^{\prime} m\right)$ である .

次に, Reachability $(v, u)$ につては, 1 回の範囲ラベ ルの比較と高々 1 回のテーブルの参照なので , 時間計算量 は $O(1)$ であり，領域計算量は $O\left(n+m+k \ell^{\prime}\right)$ である .

\section{$3 \cdot 4$ 参照テーブルの効率化と計算量}

ここでは, これまでに構筑した参照テーブルのサイズ をさらに削減する手法を提案する．ここで重要なことは， 一度参照テーブルを構筑したあとにサイズを削減するの ではなく，より少ない領域のテーブルを直接求めること ができるということである .この手法は, 到達可能性の 判定を常に $O(1)$ 時間で求める保証はないが, 深さがほ とんど変化しない XML データについては高速に計算で きる.ここでは, 本研究での手法 (分割前と分割後)およ び他の手法における計算量の比較を行う．また次の節で は, 用いたデータにおいては, 前処理に必要な計算時間， 領域量ともに, 分割前の参照テーブルと比較して効率が よいことを実験によって示す．

$R_{i j}$ をつに分割した子孫テーブルおよび先祖リスト を定義する.$R_{i j}$ と同樣に， $r_{1}, \ldots, r_{\ell}$ を被参照ノード， $v_{1}, \ldots, v_{k}$ を子孫に被参照ノードを持つノード，および $u_{1}, \ldots, u_{\ell^{\prime}}$ を先祖に被参照ノードを持つノードとする .

子孫テーブル $D_{i j}$ は, $i$ 行目が $v_{i}$ と関連付けられ,$j$ 列目が $r_{j}$ と関連付けられた配列であり， $D_{i j}=1$ は $v_{i}$ か ら $r_{j}$ に到達可能を意味する. また， $A[i]$ は長さが高々 $\ell$ のリストの先頭を指しており，光れらは $u_{i}$ の先祖からな る．したがって，A[i]指すリストが $r_{j}$ を含むとき， $r_{j}$ から $u_{i}$ に到達可能となる .

これらの構造によって , 参照テーブルは 2 分割される ことになる．これらは $R_{i j}$ を構筑するアルゴリズムとほ とんど同樣の手法で， $R_{i j}$ を経由せずに直接構築可能で ある.この樣子を図 8 に示す.この分割に対して領域 量と判定時間の関係にはトレードオフが存在する . $D_{i j}$ と $A[i]$ に分割すると, $A[i]$ の 1 ノードあたりの最大長が DOM 木の深さで制限されるため，参照テーブルを产の まま用いる場合に比べて, 必要な領域量が減少する．し かしながら, 最悪の場合, あるリストに存在するすべて のノードに対して，子孫テーブルをチェックする必要が あるため, 判定時間はリストの長さに比例して増加する．

ここで, 本手法の前処理時間, 記憶領域, および判定時 間を見積もり，他の手法と比較を行う．これまでの $R_{i j}$ で は, 表のサイズは $k \ell^{\prime}$ であったが, この分割によって , サ

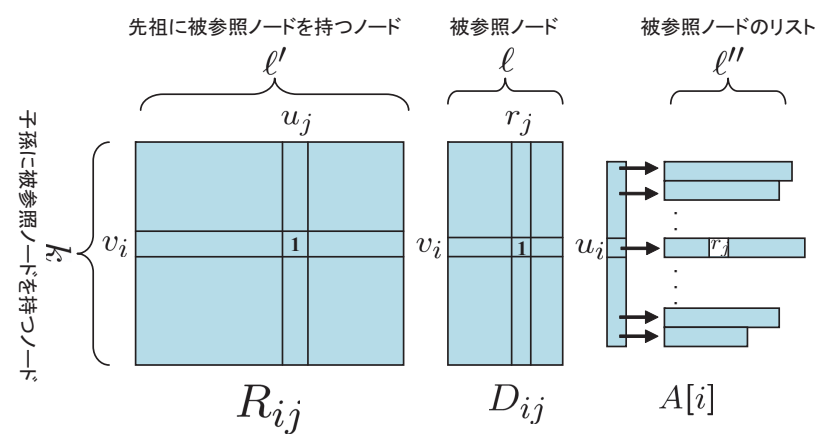

図 8 参照テーブル $R_{i j}$ を分割した子孫テーブル $D_{i j}$ と先 祖リスト $A[i]$.ただし， $\ell^{\prime \prime}$ はリストの平均長であり， 最大長ではない . 
表 1 計算量の比較: [Agrawal89, 鳥井 06, Schenkel05] と本手法 の分割前 $\left(R_{i j}\right)$ と分割後 $\left(D_{i j}+A[i]\right)$ (オーダー記号は省略)

\begin{tabular}{|c|c|c|c|c|c|}
\hline & 伝播 & 多次元 & HOPI & $R_{i j}$ & $D_{i j}+A[i]$ \\
\hline 前処理時間 & $n+p m$ & $q n^{2}+m$ & $n^{3}+m$ & $n+\ell^{\prime} m$ & $n+\ell m$ \\
\hline 領域量 & $p n+m$ & $q(n+m)$ & $n \sqrt{m}$ & $\begin{array}{c}k \ell^{\prime}+n \\
+m\end{array}$ & $\begin{array}{c}k \ell+n+m \\
+\ell^{\prime} \ell_{\text {max }}^{\prime \prime}\end{array}$ \\
\hline 判定時間 & $p$ & $q$ & $L$ & 定数 & $\ell_{\text {max }}^{\prime \prime}$ \\
\hline
\end{tabular}

イズは高々 $k \ell+\ell^{\prime} \ell^{\prime \prime}$ になる .ただし， $\ell^{\prime \prime}$ は $A[i]$ か指すリ ストの平均長である.これらの尺度について $\ell^{\prime \prime}<\ell \leq \ell^{\prime}$ であることは自明である.なぜならば， $\ell$ 個の被参照ノー ドの子孫すべてが，居 に関するノードとなるからである .

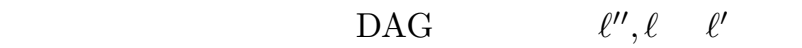
も十分に小さく，さらに $\ell^{\prime}$ は $k$ よりも十分に小さい .

結果をまとめたものを 表 1 に示す .ここで, $n$ はノー ド数， $m$ は辺数, $p$ は [Agrawal89]におけるノードひと つか持つラベルの最大数, $q$ は [鳥井 06] におけるグラ フの多次元分割数である $. \ell, \ell^{\prime}, \ell^{\prime \prime}, k$ につてはすでに説 明した．また， $\ell_{\text {max }}^{\prime \prime}$ は，先祖リストの最大長であり， $L$ は [Schenkel05] による 1 ノードあたりの平均ラベル数 (最悪は $O(n))$ である .これらの变数の大小比較について は, $n<m$ は自明であり， $\ell^{\prime \prime}<\ell \leq \ell^{\prime}<n$ であり $k<n$ である.一般に, $p$ は木の深さに依存し, $q<p$ であるこ とが実験によって示されている [鳥井 06] . これ以外の関 係はデータの複雑さに依存する . 次の節では，本手法の 効果を実験によって確認する。

\section{4. 実験}

本手法の有効性を実験によって確認する . 使用したデー タは,XMark [Schmidt02]によって生成した 3 つのXML データ $(500 \mathrm{~KB}, 2 \mathrm{MB}, 11 \mathrm{MB})$ と, XML Data Repository ${ }^{* 3}$ から取得した 2 種類の実データ Mondial(1.7MB) と TPC-H $(500 \mathrm{~KB})$ である.実験環境は，Celeron $3.2 \mathrm{GHz}$ ， 992MB メモリ上の WindowsXP であり，参照辺を含む XMLのDOM 木を C++による双方向リストで実装した 。

実験は，本手法における前処理時間，記憶領域，ノー ド間の到達可能性を判定する時間を参照テーブル分割後 の実装で測定した . また，本手法による参照テーブルの 分割前と分割後の比較および HOPI [Schenkel05] を実装 し, 性能の比較を行った .

表 2 に，使用した XML データの基本的な情報を示す． この表から，XMark は，全体のおよ光 $16 \%$ が参照辺で あり, Mondial は, 全体の $50 \%$ 近くが参照辺であること がわかる.また，平均入次数は弚の有向グラフの各ノー ドが持つ親の平均個数である.グラフが木の場合は , 根 以外がちょうど $1 つ の$ 親を持つので, 平均入次数はほぼ 1 に等しい，表 2 の 1.19 という值は, 平均して 5 ノード 中 1 つが被参照ノードであることを表す .この值が大き

*3 http://www.cs.washington.edu/research/xmldatasets/
表 2 XML データと DOM 木の概略

\begin{tabular}{|c|c|c|c|c|}
\hline データの種類 & サイズ $(\mathrm{KB})$ & 実辺数 & 参照辺数 & 平均入次数 \\
\hline & 519 & 7502 & 1456 & 1.19 \\
XMark & 2083 & 30005 & 5675 & 1.19 \\
& 11597 & 167865 & 32240 & 1.19 \\
\hline Mondial & 1740 & 22423 & 18932 & 1.89 \\
\hline TPC-H & 509 & 13648 & 1525 & 1.11 \\
\hline
\end{tabular}

表 3 参照テーブル分割前後のメモリ消費量 (カッコ内は予想值)

\begin{tabular}{|c|c||c|c|}
\hline データの種類 & $\begin{array}{c}\text { サイズ } \\
(\mathrm{KB})\end{array}$ & $\begin{array}{c}\text { 参照テーブル } \\
(\mathrm{MB})\end{array}$ & $\begin{array}{c}\text { 子孫テーブル } \\
\text { +先祖リスト (MB) }\end{array}$ \\
\hline \multirow{3}{*}{ XMark } & 519 & 12.67 & 0.56 \\
& 2083 & 208.51 & 8.54 \\
& 11597 & $(6641.42)$ & 268.65 \\
\hline Mondial & 1740 & 249.91 & 16.75 \\
\hline TPC-H & 509 & 0.42 & 0.09 \\
\hline
\end{tabular}

いほどグラフが複雑になる傾向があると考えられる．あ とで示すように，[Schenkel05]の手法では，この值が判 定時間に大きな影響を与えていることがわかる .

参照テーブルの分割前と分割後の領域を比較した結果 が，表 3 である.ただし，XMark の最大データに対す る参照テーブルについては, 必要な領域を確保できない ため, 分割後のサイズから見積もつた .この結果から , 参 照テーブルの分割によって，領域比にして数十倍の効率 化が達成されている .

HOPI との比較実験の結果を 図 9 に示す.これら結果 から，10 数 MB 程度の XMark のデータでは提案手法の 方が前処理時間と判定時間共に効率的である.また，判 定時間は，ほぼ 10 倍高速である．図 10 は，他の XML データに対する判定時間の結果である．Mondial の場合 には，本手法はほぼ 100 倍の高速化を達成している .こ れは, データが複雑になると HOPI のラベル数が急激に 増加するためである . 1ノードあたりの平均ラベル数は， XMark で8であるのに対し，Mondial では 698 に増加 した .これに対し，本手法における先祖リストの最大長 は，XMark の各データで1であり，Mondial でも 3 で ある．この結果から，参照辺が多く含まれるデータほど 本手法の効果が得られやすいことがわかる．以上の結果 から，本研究て提案した手法によって，高速な到達可能 性判定に対して期待した効果が得られたと考えられる .

\section{5. ま と め}

本研究では, 木構造よりも複杂倠な XML データに対し て，高速に頂点間の到達可能性を判定するためのアルゴ リズムを提案した . 提案手法では，XML データ内の偏り を仮定し，弚れらの情報を利用して，判定の効率をほと んど犠牲にすることなく参照テーブルのサイズを大幅に 削減した．また光の手法を実装して，現実のデータや他 


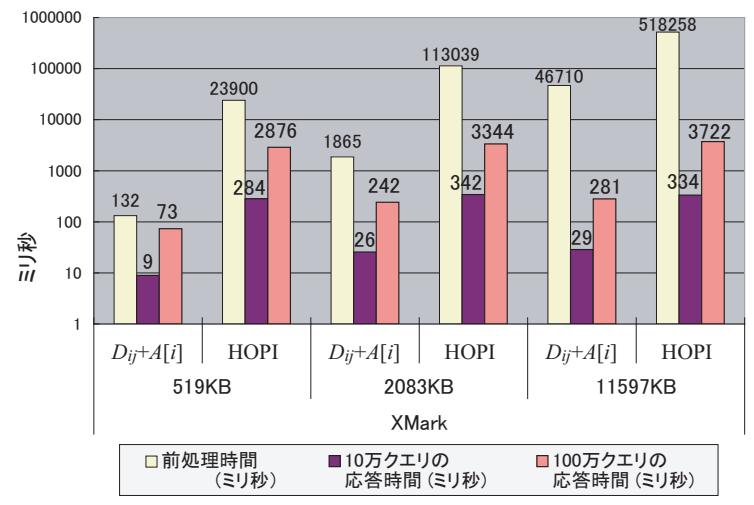

図 9 XMark における比較実験

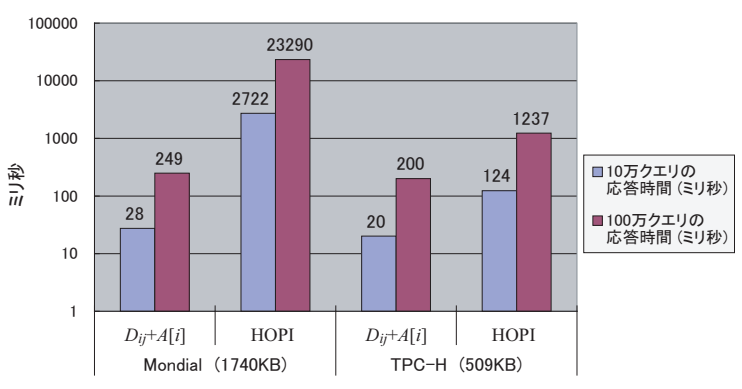

図 10 実データにおける比較実験

の手法と比較して有効性を確かめた．しかしながら，今 回比較した HOPIは，XML データを分割することでよ り大規模な XML データに適用可能であるのに対し，本 手法は今のところ ,データを分割することができない，ま た，[Schenkel05]では, インデックスの更新についても 提案されており，本研究の今後の課題である .

\section{$\diamond$ 参 考 文 献 $\diamond$}

[Abiteboul00] S. Abiteboul, P. Buneman, D. Suciu, Data on the Web, Morgan Kaufmann (2000)

[Abiteboul01] S. Abiteboul, H. Kaplan, T. Milo, Compact labeling schemes for ancestor queries, In SODA 2001, pp. 547$556(2001)$

[Aboulnaga01] A. Aboulnaga, A. R. Alameldeen, J.F. Naughton, Estimating the Selectivity of XML Path Expressions for Internet Scale Applications, In VLDB 2001, pp. 591-600 (2001)

[Agrawal89] R. Agrawal, A. Borgida, H.V. Jagadish, Efficient Management of Transitive Relationships in Large Data and Knowledge Bases, In SIGMOD 1989, pp. 253-262 (1989)

[Aho87] A. V. Aho, J. E. Hopcroft, J. D. Ullman, Data Structures and Algorithms, Addison-Wesley (1987)

[Al-Kalifa02] S. Al-Khalifa, H. V. Jagadish, N. Koudas, J. M. Patel, D. Srivastava, Y. Wu, Structural Joins: A Primitive for Efficient XML Query Pattern Matching, In ICDE 2002, pp. 141- (2002)

[Arion03] A. Arion, A. Bonifati, G. Costa, S. D'Aguanno, I. Manolescu, A. Pugliese, Xquec: pushing queries to compressed XML data, In VLDB 2003, pp. 1065-1068 (2003)

[Betc02] S. Boag, D. Chamberlin, M. F. Fernandez, D. Florescu, J. Robie, J. Simeon, XQuery 1.0: An XML Query Language,
http://www.w3.org/TR/2002/WD-xquery-20020816 (2002)

[BPSM98] T. Bray, J. Paoli, C. M. Sperberg-McQueen, E. Maler, Extensible Markup Language (XML) 1.0 W3C Recommendation, http://www.w3.org/TR/REC-xml (1998)

[Chen05] L. Chen, A. Gupta, M. E. Kurul, Efficient Algorithms for Pattern Matching on Directed Acyclic Graphs, In ICDE 2005, pp. 384-385 (2005)

[Chung02] C.-W. Chung, J.-K. Min, K. Shim, APEX: Adaptive Path Index for XML Data, In SIGMOD 2002, pp. 121$132(2002)$

[Kaplan02] E. Cohen, E. Halperin, H. Kaplan, U. Zwick Reachability and Distance Queries via 2-Hop Labels, In SODA 2002, pp. 937-946, 2002.

[Cohen02] E. Cohen, H. Kaplan, T. Milo, Labeling Dynamic XML Trees, In PODS 2002, pp. 271-281 (2002)

[江田 02] 江田毅晴, 天笠俊之, 吉川正俊, 植村俊亮, XML 木の ための更新に強い節点ラベル付け手法, DBSJ Letters, Vol. 1, No. 1, pp. 35-38 (2002)

[Fernandez98] M. F. Fernandez, D. Suciu, Optimizing Regular Path Expressions Using Graph Schemas, In ICDE 1998, pp. 13-23 (1998)

[Goldman97] R. Goldman, J. Widom, DataGuides: Enable Query Formulation and Optimization in Semistructured DataBases, In VLDB 1997, pp. 436-445 (1997)

[Green04] T. J. Green, A. Gupta, G. Miklau, M. Onizuka, D. Suciu, Processing XML Streams with Deterministic Automata and Stream Indexes, ACM TODS, vol. 29, no. 4 (2004)

[Lam03] W.-Y. Lam, W.-N. Peter, M. Levene, XCQ: XML Compression and Querying System, In WWW 2003 (posters) (2003)

[Maita05] T. Maita, H. Sakamoto, A Simple Extension of Queriable Compression for XML Data, In AMT 2005, pp. 91-95 (2005)

[Milo99] T. Milo, D. Suciu, Index structures for path expressions, In ICDT 1999, pp. 277-295 (1999)

[Min03] J.-K. Min, M.-J. Park, C.-W. Chung, XPRESS: A Queriable Compression for XML Data, In SIGMOD 2003, pp. 122-133 (2003)

[Schenkel05] R. Schenkel, A. Theobald,G. Weikum, Creation and Incremental Maintenance of the HOPI Index for Complex XML Document Collections, In ICDE 2005, pp. 360371 (2005)

[Schmidt02] A. Schmidt, F. Waas, M. Kersten, M. Carey, I. Manolescu, R. Busse, Xmark: A benchmark for XML data management, In VLDB 2002, pp. 974-985 (2002)

[Schwentick04] T. Schwentick, XPath Query Containment, SIGMOD Record, Vol. 33, No. 1, pp. 101-109, (2004)

[Srivastava02] D. Srivastava, S. Al-Khalifa, H. V. Jagadish, N. Koudas, J. M. Patel, Y. Wu, Structural joins: A primitive for effcient XML query pattern matching, In ICDE 2002, pp. 141-152 (2002)

[Tolani02] P. M. Tolani, J. R. Haritsa, XGRIND: A Queryfriendly XML Compressor, In ICDE 2002, pp. 225-234 (2002)

[鳥井 06] 鳥井修, 白井智, 金井達德, 非巡回グラフのための拡張レ ンジラベリング手法, DBSJ Letters, Vol.5, No.1, pp.157-160 (2006)

[Wu03] Y. Wu, J. M. Patel, H. V. Jagadish, Structural Join Order Selection for XML Query Optimization, In ICDE 2003, pp. 443-454 (2003)

[Zhang01] C. Zhang, J. Naughton, D. DeWitt, Q. Luo, G. Lohman, On Supporting Containment Queries in Relational Database Management Systems, In SIGMOD 2001, pp. 425$436(2001)$

〔担当委員 : 河野 浩之〕

2006 年 8 月 15 日 受理 
謝 辞

本研究の一部は平成 18 年度科学研究費補助金 (若手研 究 (B) 課題番号 18700154) による支援を受けて実施され ました．また，本論文を執筆するにあたり査読者の方々 から有益なコメントを頂きました . ここに記して謝意を 表します.

著者紹介

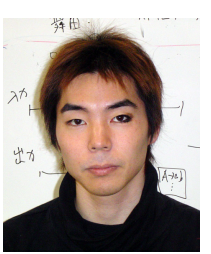

中村 有作

2006 年九州工業大学情報工学部知能情報工学科卒業，現 在, 同大学院情報工学研究科情報科学専攻修士課程に在学 中. 半構造データからのデータマイニング, 効率的な索引 構造の研究に従事

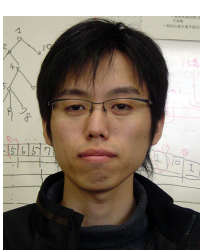

舞田 哲哉

2005 年九州工業大学情報工学部知能情報工学科卒業. 現 在, 同大学院情報工学研究科情報科学専攻修士課程に在学 中. 高速な XML データベース, 大規模な半構造データ の索引付けに関する研究に従事 .

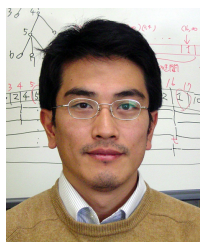

坂本 比呂志(正会員)

1998 年 12 月九州大学大学院システム情報科学研究科情 報理学専攻博士後期課程修了 (日本学術振興会特別研究員) 博士 (理学) . 1999 年 1 月から 2003 年 7 月まで九州大 学大学院システム情報科学研究科助手. 2003 年 8 月か ら九州工業大学情報工学部助教授で現在に至る。機械学習 と Web 上のテキストデータからの知諳獲得の研究に従事 最近は XML データの圧縮および索引付けに関する研究 に興味を持っている。 